\title{
Stuck in the mud: suspended sediments as a key issue for survival of chrysomonad flagellates
}

\author{
Karin Pfandl*, Jens Boenigk \\ Institute for Limnology, Austrian Academy of Sciences, Mondseestr. 9, 5310 Mondsee, Austria
}

\begin{abstract}
The effect of suspended fine sediments on chrysomonad flagellates was investigated for 'Spumella-like' flagellates in laboratory studies and exemplarily for a flagellate community (with a focus on chrysomonads) originating from the oligomesotrophic Lake Mondsee, Austria, using different clay minerals and silicate beads. In the community experiment, the abundances of Spumella-like flagellates decreased significantly after introduction of suspended clays, but on the community level suspended clays did not negatively affect flagellate abundance. In order to understand this taxonspecific response, the influence of different clay characteristics, specifically of particle concentration and size, was investigated for Spumella-like flagellates in laboratory studies. We used ultramicrobacteria, i.e. typical bacterioplankton of Lake Mondsee, as food. For comparison we also investigated growth rates of the Spumella-like flagellates feeding on the large bacterium Listonella pelagia. These experiments confirmed that at bacterial abundances realized in oligotrophic and mesotrophic lakes, the flagellates are severely food limited. The presence of suspended sediments generally decreased the growth at any food concentration tested. This decrease was reflected in shifts of the growth kinetic parameters, i.e. in a positive correlation between the half-saturation constant and the threshold food concentration and a negative correlation between the maximal growth rate and the suspended sediment concentration. The clearance rates strongly decreased when small and large particles were present, but were only slightly affected for intermediate-sized particles. We assume that small particles in the size range of ingestible bacteria interfere with the feeding process and cause lower clearance rates, while intermediate-sized particles may serve as substrate for the attachment of flagellates and to subsequently optimize their clearance rates.
\end{abstract}

KEY WORDS: Turbidity · Growth rates · Microbial food web · Grazing · Chrysophytes/ Chrysomonads $\cdot$ HNF $\cdot$ Protists $\cdot$ Turbulence

Resale or republication not permitted without written consent of the publisher

\section{INTRODUCTION}

Despite the general importance of suspended sediments in freshwater systems, specifically after precipitation or flood events (e.g. Serruya 1974, Threlkeld 1986, Lenzi \& Marchi 2000), their interference with the feeding and growth of microbial components is severely understudied and largely unknown. In lakes, suspended sediment concentrations are typically in the range of several milligrams per liter, but may increase several orders of magnitude within hours following precipitation (Dokulil 1979, Knowlton \& Jones 1995). In streams, suspended sediment concentrations are generally high, and, specifically, in many lowland streams average concentrations are between 100 and $20000 \mathrm{mg} \mathrm{l}^{-1}$ (Arruda et al. 1983, Eisma 1993, Brondson \& Naden 2000, Orton \& Kineke 2001). Despite the ubiquity of suspended sediments and the presumably great effect on microorganisms and particularly on protists, these interrelationships have not been thoroughly studied.

In the present study, we investigated the effect of suspended sediments on bacterivorous protists, for a common and generally abundant flagellate group, i.e. for colorless chrysophytes, often a dominant component of the microbial food web. Finlay \& Esteban (1998) stated that heterotrophic heterokonts, and specifically chrysomonads, are 'probably the most 
abundant of the heterotrophic flagellates in the plankton (e.g. Paraphysomonas and 'Spumella-like' flagellates) and the most important [...] grazers of bacteriasized microorganisms'. Annually, on average, 20 to $50 \%$ of the pelagic heterotrophic nanoflagellate (HNF) biomass in freshwaters is formed by small heterokont taxa, mainly colorless chrysophytes (i.e. chrysomonads) and bicosoecids (Salbrechter \& Arndt 1994, Carrias et al. 1998, Arndt et al. 2000).

Based on theoretical assumptions and the few available experimental studies (England et al. 1993, Jack \& Gilbert 1993, Boenigk \& Novarino 2004), suspended sediments are expected to affect pelagic protists in several ways. On the one hand, suspended sediments may decrease feeding efficiency and protist population growth, due to interference with the feeding process and/or mechanical damage to fragile protist cells especially in turbid environments (Boenigk \& Novarino 2004). Interference with feeding can specifically be expected for interception-feeding pelagic flagellates (e.g. chrysomonads). On the other hand, suspended solids may serve as a substratum for the attachment of chrysomonad flagellates, thus indirectly triggering their feeding efficiency (ChristensenDalsgaard \& Fenchel 2003, Kiørboe et al. 2004). These effects of suspended solids are further modified as dissolved substances attach easily to suspended sediment particles. Thus, the bioavailability of nutritive as well as harmful substances is modified (Boenigk et al. 2005a), which may not only affect the flagellates, but also their bacterial prey (Lind et al. 1997). Besides these effects on nutrient availability, sediment particles may provide an indirect grazing protection for bacteria, as bacterivorous predators confronted with high abundances of indigestible nanoparticles may fail to ingest bacteria at high rates (England et al. 1993, Jack \& Gilbert 1993).

The potential response of chrysomonad flagellates to suspended sediments is therefore expected to be complex. Our understanding of these interactions, however, is severely limited. The lack of experimental studies is probably due to the fact that suspended sediments have been largely disregarded as an important factor for heterotrophic microorganisms. The particle characteristics that are responsible for shifts in the protist population response are unknown, and the ecological significance of suspended particles for heterotrophic flagellate taxa is largely restricted to rough assumptions (Boenigk \& Novarino 2004).

We focused our investigations on chrysomonad flagellates for 2 reasons: (1) colorless chrysophytes are among the most dominant bacterivores in many aquatic habitats (see above) and (2) despite the positive effect of suspended sediments on chrysomonad flagellates, as reported by Boenigk \& Novarino (2004), these flagellates are theoretically expected to be negatively affected by suspended sediments, thus demanding further in-depth investigations. We hypothesized that suspended sediments negatively affect chrysomonad flagellates and that the strength of this effect depends on particle concentration and size characteristics. In order to test these hypotheses, we investigated the effect of suspended particles on pelagic chrysophytes using a natural community taken from Lake Mondsee, Austria, and a set of specific laboratory experiments testing the effect of suspended sediments on the growth of 'Spumella-like' flagellates.

\section{MATERIALS AND METHODS}

Origin of strains, culture conditions and origin of clays. Single-cell, colorless chrysophytes are common and abundant in the plankton of many lakes and streams (see 'Introduction'). Experiments were conducted using 'Spumella-like' flagellates (Spumella sp., Chrysophyceae, Chromulinaceae) as model organisms. The flagellate strain JBC07 $\left(61.1 \pm 24.8 \mu^{3}\right)$ was isolated from the eutrophic shallow lake Tai $\mathrm{Hu}$, China, and the flagellate strain JBM10 (69.3 \pm $17.8 \mathrm{\mu m}^{3}$ ) was isolated from a pond located in Mondsee, Austria (Boenigk et al. 2005b). Both flagellate strains are affiliated with the C3 cluster of the Chrysophyceae and are common freshwater flagellates (Boenigk et al. 2005b). They are able to predate on ultramicrobacteria (Boenigk et al. 2005c). The axenic protist strains were cultured in NSY basal medium (Hahn et al. 2003) on a diet of the heat-killed bacterial strain Listonella pelagia CB5 and were transferred weekly to fresh medium. Cultures were kept at $16^{\circ} \mathrm{C}$ in permanent light $\left(8.9 \mu \mathrm{E} \mathrm{m}^{-2} \mathrm{~s}^{-1}\right)$.

The large bacterial strain Listonella pelagia CB5 $\left(0.38 \pm 0.2 \mu^{3}\right)$ and the ultramicrobacterial strain MWH-MoNR1 $\left(0.04 \pm 0.017 \mu^{3}\right.$; closest known relative Clavibacter michiganensis [Microbacteriaceae]) were used as living food bacteria in the experiments (Hahn \& Höfle 1998, Hahn 2003). The bacterial strains were cultured in NSY basal medium supplemented with equal amounts (1 $\mathrm{g}$ each) of nutrient broth, soyotone and yeast extract (Hahn et al. 2003). Before the experiments were started, bacteria were repeatedly centrifuged for $15 \mathrm{~min}$ at $5000 \times g$ and washed with NSY basal media to remove traces of DOM. Microscopic analysis showed that the flagellate strain MWHMoNR1, which was used in the suspended sediment experiments, does not aggregate or attach to the suspended particles.

All flagellate and bacterial strains originate from oligomesotrophic lakes and represent common freshwater organisms. 
Two natural clays and artificial silicate particles were used in the experiments: a kaolinite-dominated clay (gray clay: $84 \%$ kaolinite, $3 \%$ other clay minerals; zeta potential $-47 \mathrm{mV}$ ) and a kaolinite/montmorillonite clay (yellow clay: $40 \%$ montmorillonite, $~ 60 \%$ kaolinite; zeta potential $-26 \mathrm{mV}$ ), both originating from a clay pit in the Eifel, Germany (Fig. 1); Kaolinite, i.e. the end-product of weathering of silicates, and montmorillonite are among the dominant clay minerals in most soils of the temperate region. Therefore, these minerals are expected to dominate the clay and silt fraction of suspended sediments in surface waters after precipitation and were thus selected for our experiments.

In addition, artificial silicate particles (sicastar, micromode: $0.1 \mu \mathrm{m}$ diameter, Art.-No. 43-00-102; $0.4 \mu \mathrm{m}$ diameter, Art.-No. 43-00-402; $0.8 \mu \mathrm{m}$ diameter, Art.-No. 43-00-802, zeta potential-61.5 mV; $1.5 \mu \mathrm{m}$ diameter, Art.-No. 43-00-153; 3 um diameter, Art.-No. 43-00-303; $15 \mu \mathrm{m}$ diameter, Art.-No. 43-00-154) were used as standardized basis particles. Silicate beads possess a silanol surface and therefore show a strong negative surface charge, as is also the case in natural clays. In contrast to natural particles, the surface layer of these particles and their chemical composition is defined.

Influence of suspended particles on the growth of a freshwater flagellate community. The sample, containing a natural assemblage of flagellates, was collected from the surface water of Lake Mondsee. The

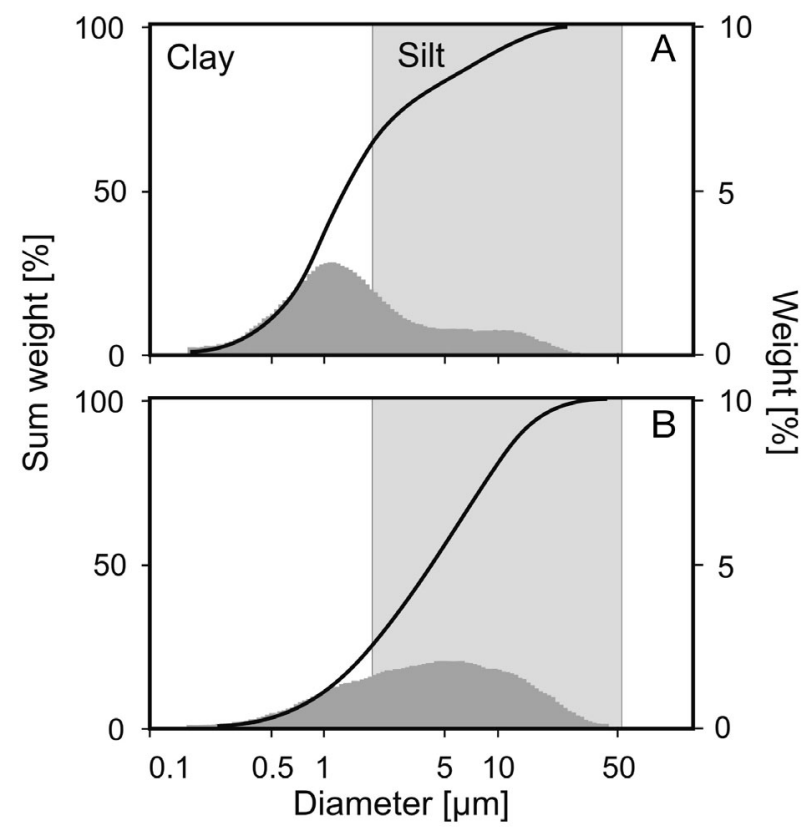

Fig. 1. Grain size distribution of the (A) kaolinite-dominated and the (B) kaolinite/montmorillonite clay. Grain-size distribution (dark gray area) and sum weight curve (solid line) are shown for the original clay as obtained from the clay pit. Note the logarithmic scale of the abscissa water was gently filtered through a $11 \mu \mathrm{m}$ polycarbonate filter (Millipore) to exclude larger predators such as planktonic ciliates and metazoans.

The sample was divided into 4 subsamples of $180 \mathrm{ml}$ each. Three of the 4 subsamples were supplemented with artificial particles, e.g. gray clay, yellow clay and $0.8 \mu \mathrm{m}$ beads, to a final concentration of $10 \mathrm{mg} \mathrm{l}^{-1}$ (corresponds to approximately $4.2 \times 10^{6}, 2.9 \times 10^{5}$ and $1.49 \times 10^{7}$ particles $\mathrm{ml}^{-1}$ for the gray clay, the yellow clay and the $0.8 \mu \mathrm{m}$ beads, respectively). The concentration of $10 \mathrm{mg} \mathrm{l}^{-1}$ is well within densities reported in natural systems, and the particle size range is typical for lakes and lowland streams (Dokulil 1979, Ritchie et al. 1986). The samples were again subdivided into 3 replicates of $60 \mathrm{ml}$ each. Experiments were run in $100 \mathrm{ml}$ Schott flasks and incubated on an overhead shaker (Stuart STR4) at 10 rotations $\min ^{-1}, 15^{\circ} \mathrm{C}$ and

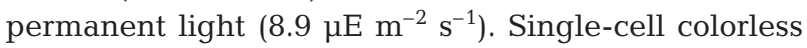
chrysophytes (Spumella-like), pigmented chrysophytes (Ochromonas/Chromulina) and total number of heterotrophic flagellates were counted daily in live subsamples for $7 \mathrm{~d}$ using a Zeiss Axiovert 135 at 200× magnification under phase contrast. In total, at least 80 flagellate cells were counted per sample.

Bacterial abundances were checked by epifluorescence microscopy: $0.5 \mathrm{ml}$ of the sample was fixed with Lugol's solution $(0.5 \%$ final concentration, f.c.) and formaldehyde ( $2 \%$ f.c.), bleached with some drops of thiosulfate, stained with DAPI ( $2 \mu \mathrm{g} \mathrm{ml} \mathrm{m}^{-1}$ f.c.) and filtered onto black polycarbonate filters $(0.2 \mu \mathrm{m})$. At least 400 bacterial cells were counted per sample using a Zeiss Axiophot microscope at $1250 \times$ magnification.

Growth of Spumella-like flagellates feeding on different food sources. Growth rates of Spumella-like flagellates feeding on live prey, e.g. the large bacterium Listonella pelagia CB5 and the small bacterium MWH-MoNR1, were determined.

Growth of the flagellate strain JBC07 was tested at different bacterial abundances between 0.1 and $200 \times$ $10^{6}$ bacteria $\mathrm{ml}^{-1}$ and for a no-food control. Flagellates were adapted to the respective food conditions $24 \mathrm{~h}$ before initiation of the experiment. All experiments were run in NSY inorganic basal medium at $16^{\circ} \mathrm{C}$ in the dark. Initial experimental volume was $50 \mathrm{ml}$ in $100 \mathrm{ml}$ SCHOTT flasks. Start abundance of flagellates was adjusted to $1-2 \times 10^{3}$ flagellates $\mathrm{ml}^{-1}$. The first subsamples were taken after $3 \mathrm{~h}$, and subsamples of $3 \mathrm{ml}$ were taken every $3 \mathrm{~h}$ for a period of $15 \mathrm{~h}$. All subsamples were fixed with formaldehyde ( $2 \%$ f.c.), stored at $4^{\circ} \mathrm{C}$ and further processed within $2 \mathrm{~d}$. Preliminary experiments proved that DAPI occasionally did not stain the flagellate cells, even when using a high concentration of stain and long incubation times (data not shown). Therefore, a staining protocol using a mixture of SYBR Green I (Molecular Probes) and DAPI was 
applied. Briefly, $1 \mathrm{ml}$ of the subsample was stained with SYBR Green I (10000-fold final dilution of the stock solution) and DAPI (20 $\mu \mathrm{g} \mathrm{ml}^{-1}$ f.c.) for $30 \mathrm{~min}$, filtered onto black $0.2 \mu \mathrm{m}$ Nucleopore filters (Millipore) backed by $0.45 \mu \mathrm{m}$ polycarbonate filters (Millipore) and stored at $-20^{\circ} \mathrm{C}$ until inspection. Flagellates were counted under an epifluorescence microscope using UV and blue excitation. At least 80 individuals were counted per sample. Growth rates were calculated from the exponential growth phase.

Growth rates for strain JBM10 were taken from Boenigk et al. (2006). These growth rates were obtained in a similar way as for the flagellate strain JBC07.

Growth rates of flagellates feeding on the small and large bacterium were manually fitted to the Michaelis-Menten equation using non-linear regression, such that:

$$
\mu=\mu_{\max } \times \frac{C-i}{K_{m}+C-i}
$$

where $\mu_{\max }$ is the maximal growth rate $\left(\mathrm{d}^{-1}\right), c$ is the bacterial abundance (bacteria $\mathrm{ml}^{-1}$ ), $i$ is the bacterial threshold food concentration for growth (bacteria $\mathrm{ml}^{-1}$ ), and $K_{m}$ is the half-saturation constant (bacteria $\left.\mathrm{ml}^{-1}\right)$.

Effect of suspended particles on Spumella-like flagellates. The presence of suspended sediments in these experiments demanded permanent (over head) shaking to keep particles in suspension. Shaking avoided sedimentation of the suspended particles, and microscopic analysis provided evidence that the particles were suspended homogenously and did not aggregate in the suspension during the experiment (data not shown). Preliminary experiments further showed that the flagellates needed a longer time to acclimatize to these conditions. Therefore, flagellates were acclimatized to the experimental conditions (i.e. food concentration and turbulence [shaking at 10 rotations $\min ^{-1}$ ]) for $3 \mathrm{~d}$ before the experiments were started. The ultramicrobacterium MWH-MoNR1 was used as live prey. The food concentration was checked daily using epifluorescence microscopy and adjusted by either adding food or diluting the medium. Experiments were carried out in $100 \mathrm{ml}$ flasks mounted to an overhead rotator (Stuart STR4). Generally, abundances of flagellates at the beginning of the experiments were approximately $5000 \mathrm{ml}^{-1}$, except at low food concentrations when flagellate abundances were adjusted to approximately $1000 \mathrm{ml}^{-1}$.

First set of experiments - influence of particle concentration on growth: To assess the growth rates at different particle loads, flagellates were acclimatized to food concentrations of $0.1,0.2,1,3,5,10,20$ and $50 \times$ $10^{6}$ bacteria $\mathrm{ml}^{-1}$. When the experiment was started, silicate beads with $0.8 \mu \mathrm{m}$ diameter were added at 5 different concentrations $\left(0,1,5,20\right.$ and $\left.100 \mathrm{mg} \mathrm{l}^{-1}\right)$. All experiments were run in 3 replicates. Final sample volume at the start of the experiments was $30 \mathrm{ml}$, and subsamples of $3 \mathrm{ml}$ were taken every 6 (JBC07) and $4 \mathrm{~h}$ (JBM10) for a period of $24 \mathrm{~h}$ for analysis. Subsamples were fixed, and $1 \mathrm{ml}$ of each subsample was stained and inspected using epifluorescence microscopy as described above (see 'Growth of Spumella-like flagellates feeding on different food sources' section, above). All experiments were run in 3 replicates.

Growth rates of flagellates were calculated from the exponential growth phase. Growth rates from each of the treatments containing different concentrations of suspended particles were fitted to the MichaelisMenten equation (see 'Growth of Spumella-like flagellates feeding on different food sources' section, above) using non-linear regression.

Second set of experiments - influence of particle size on the feeding process: In another set of experiments, the effect of particle size on the flagellate strain JBC07 was investigated. We determined clearance rates as we expected that the interference with feeding and the attachment to particles, consequently increasing filtration efficiency, are the major components affecting flagellate-particle interaction. In these experiments the food concentration was adjusted to $3 \times$ $10^{6}$ bacteria $\mathrm{ml}^{-1}$. Particles of different sizes $(0.1,0.4$, $0.8,1.5,3$ and $15 \mu \mathrm{m}$ ) were added at a final particle load of $10 \mathrm{mg} \mathrm{l}^{-1}$ (corresponds to approximately $7.6 \times$ $10^{9}, 1.2 \times 10^{8}, 1.49 \times 10^{7}, 2.26 \times 10^{6}, 2.8 \times 10^{5}$ and $2.3 \times$ $10^{3}$ particles $\mathrm{ml}^{-1}$ for the $0.1,0.4,0.8,1.5,3$ and $15 \mu \mathrm{m}$ beads, respectively) and at a final particle abundance of $1.49 \times 10^{7}$ particles $\mathrm{ml}^{-1}$ (corresponds to approximately $0.02,1.25,10,66,527$ and $66000 \mathrm{mg} \mathrm{l}^{-1}$ for the $0.1,0.4,0.8,1.5,3$ and $15 \mu \mathrm{m}$ beads, respectively). Final sample volume at the start of the experiments was $25 \mathrm{ml}$, and subsamples of $3 \mathrm{ml}$ were taken every $2 \mathrm{~h}$ for a period of $24 \mathrm{~h}$. Subsamples were fixed, and $1 \mathrm{ml}$ of each subsample was stained to check bacterial abundances using epifluorescence microscopy as described above (see 'Influence of suspended particles on the growth of a freshwater flagellate community' section, above). At least 400 bacterial cells were counted per sample. All experiments were run in 3 replicates.

Clearance rates $\left(\mathrm{h}^{-1}\right)$ of the flagellate strain JBC07 feeding on the ultramicrobacterium MWH-MoNR1 were calculated according to the following formula:

$$
F=\frac{g \times 10^{6}}{N_{\text {prey }}} / 24
$$

where $g$ is the grazing rate of Spumella $\left(g=\mu_{\text {prey- }}\right.$ control $-\mu_{\text {prey-experiment }}$ ) and $N_{\text {prey }}$ is the mean bacterial abundance during the period of incubation. 
Statistical analysis. All statistical tests, specifically the ANOVA and $t$-tests for comparison of growth rates and clearance rates, were performed using the software package SigmaStat 2.03.

\section{RESULTS}

\section{Incubation experiment}

Bacterial abundances did not significantly vary during the period of incubation in any of the treatments (ANOVA, $p>>0.05$ ) and were $5.02 \pm 0.57$ and $4.69 \pm$ $0.15 \times 10^{6}$ bacteria $\mathrm{ml}^{-1}$ (control treatment), $4.69 \pm 0.48$ and $4.37 \pm 0.15 \times 10^{6}$ bacteria $\mathrm{ml}^{-1}(0.8 \mu \mathrm{m}$ beads), 3.14 \pm 0.26 and $3.14 \pm 0.37 \times 10^{6}$ bacteria $\mathrm{ml}^{-1}$ (gray clay) and $4.03 \pm 0.89$ and $3.66 \pm 0.29 \times 10^{6}$ bacteria $\mathrm{ml}^{-1}$ (yellow clay) at the beginning and the end of the experiment, respectively.

In the control treatment the flagellate community showed low, but significant growth $\left(\mu=0.05 \pm 0.02 \mathrm{~d}^{-1}\right.$; $t$-test $\left.t_{i}=0.021\right)$. In the presence of suspended sediments, community growth was significantly higher for silicate beads and the kaolinite-dominated clay (gray clay) $(\mu=0.14 \pm 0.05, p=0.017$ and $\mu=0.13 \pm 0.004, p=$ 0.019 , respectively), but not for the kaolinite/montmorillonite (yellow clay) $(\mu=0.06 \pm 0.02, p=0.938)$. In contrast to this community response, the abundance of solitary chrysophytes decreased in all treatments (Fig. 2). Mortality of Spumella-like flagellates was significantly higher when suspended sediments were present for all sediment types (ANOVA; Tukey test; $\mathrm{p}<$ $0.001, p=0.023$ and $p=0.014$ for beads, kaolinitedominated clay and kaolinite/montmorillonite, respec-

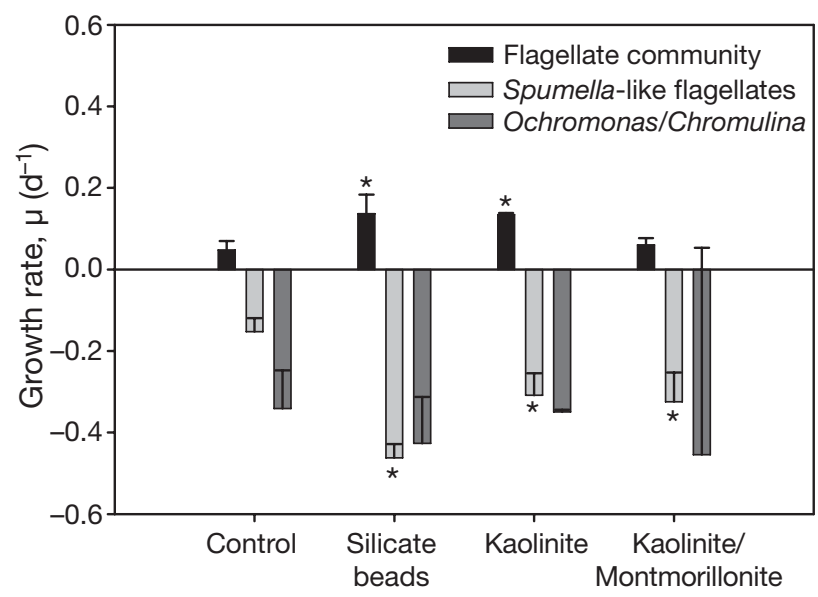

Fig. 2. Growth rates of a flagellate community originating from Lake Mondsee and specifically of solitary chrysophytes, i.e. 'Spumella-like' flagellates and Ochromonas/Chromulina, in the presence of different suspended particles. *: growth rates that are significantly different (ANOVA; Tukey test) from the respective growth rate in the control treatment tively; Fig. 2). For Ochromonas/Chromulina, suspended sediments did not significantly alter the mortality rate (ANOVA; Tukey test; $\mathrm{p}>>0.05$ for all clay types).

\section{Growth in the absence of suspended sediments}

Growth rates of the flagellate strain JBC07 as a function of food concentration corresponded to saturation kinetics (Michaelis-Menten equation). Maximum growth rate when fed with the large bacterium CB5 $\left(\mu_{\max }\right)$ was $2.8 \mathrm{~d}^{-1}$, the half-saturation constant $\left(K_{m}\right)$ was $1.2 \times 10^{6}$ bacteria $\mathrm{ml}^{-1}$ and the threshold food concentration (i) for positive growth was $0.3 \times 10^{6}$ bacteria $\mathrm{ml}^{-1}$. When the ultramicrobacterial strain $\mathrm{MWH}-$ MoNR1 was used as bacterial food, $i$ was $6.5 \times 10^{6}$ bacteria $\mathrm{ml}^{-1}, K_{m}$ was $22 \times 10^{6}$ bacteria $\mathrm{ml}^{-1}$ and $\mu_{\max }$ was $2.3 \mathrm{~d}^{-1}$ (Fig. 3). Growth rates of the flagellate strain JBM10 growing on the bacteria CB5 and MWHMoNR1 are provided in Boenigk et al. (2006).

\section{Growth in the presence of different concentrations of suspended sediments}

Growth in the presence of suspended sediments still corresponded to saturation kinetics (Michaelis-Menten equation). The growth kinetic parameters depended on the concentration of suspended sediment $\left(S, \mathrm{mg} \mathrm{l}^{-1}\right)$, i.e. $\mu_{\max }$ decreased, whereas $K_{m}$ and $i$ increased (Figs. 4 \& 5). $i$ increased linearly with $S: i=0.23 \times S+2.7617\left(\mathrm{r}^{2}=\right.$ $0.99)$ and $i=0.229 \times S+1.201\left(\mathrm{r}^{2}=0.99\right)$ for Spumella strains JBC07 and JBM10, respectively. Similarly, $K_{m}$ increased linearly with $S: K_{m}=0.194 \times S+8.01\left(\mathrm{r}^{2}=\right.$ $0.98)$ and $K_{m}=0.179 \times S+5.596\left(r^{2}=0.99\right)$ for Spumella strains JBC07 and JBM10, respectively. $\mu_{\max }$ of the flagellates decreased exponentially with increasing $S$ : $\mu_{\max }=1.90 \times \mathrm{e}^{-0.0337 \times S}\left(\mathrm{r}^{2}=0.99\right)$ and $\mu_{\max }=1.36 \times \mathrm{e}^{-0.1284}$ $\times S\left(r^{2}=0.96\right)$ for Spumella strains JBC07 and JBM10, respectively (Fig. 5). Based on the coefficient of determination (adjusted $\mathrm{r}^{2}$ ), the models explained 90.4 and $85.4 \%$ of the observed variation for the growth rates of JBC07 and JBM10, respectively (Fig. 4), whereas food concentration alone explained only 70.9 and $39.6 \%$ for JBC07 and JBM10, respectively.

\section{Effect of particle size on the clearance rate}

We suspected that the predominant negative effect of suspended particles is largely due to interference with feeding, and further that this interference is correlated to particle size. We therefore investigated the effect of particle size on the clearance rate. 

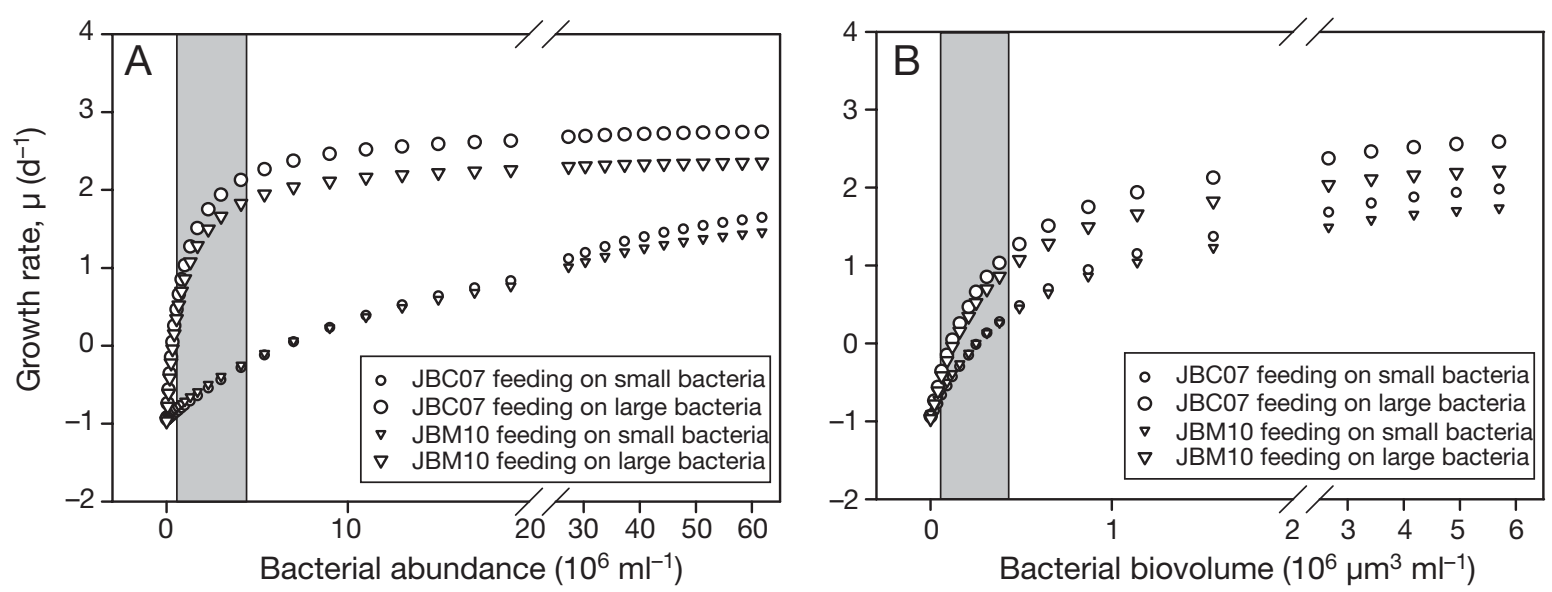

Fig. 3. Spumella sp. Growth rate as a function of (A) bacterial abundance and (B) bacterial biovolume for the flagellate strains JBC07 and JBM10 based on non-linear regression models (for explanation see 'Materials and methods'): $\mu=2.8 \times(C-0.3 \times$ $\left.10^{6}\right) /\left(1.2 \times 10^{6}+c-0.3 \times 10^{6}\right)$ and $\mu=2.3 \times\left(c-6.5 \times 10^{6}\right) /\left(22 \times 10^{6}+c-6.5 \times 10^{6}\right)$ for the flagellate strain JBC0 7 feeding on the large and the small bacterium, respectively. Growth rates of the flagellate strain JBM10 are provided in Boenigk et al. (2006). Gray area indicates bacterial abundances and biovolumes usually realized in oligotrophic to mesotrophic environments

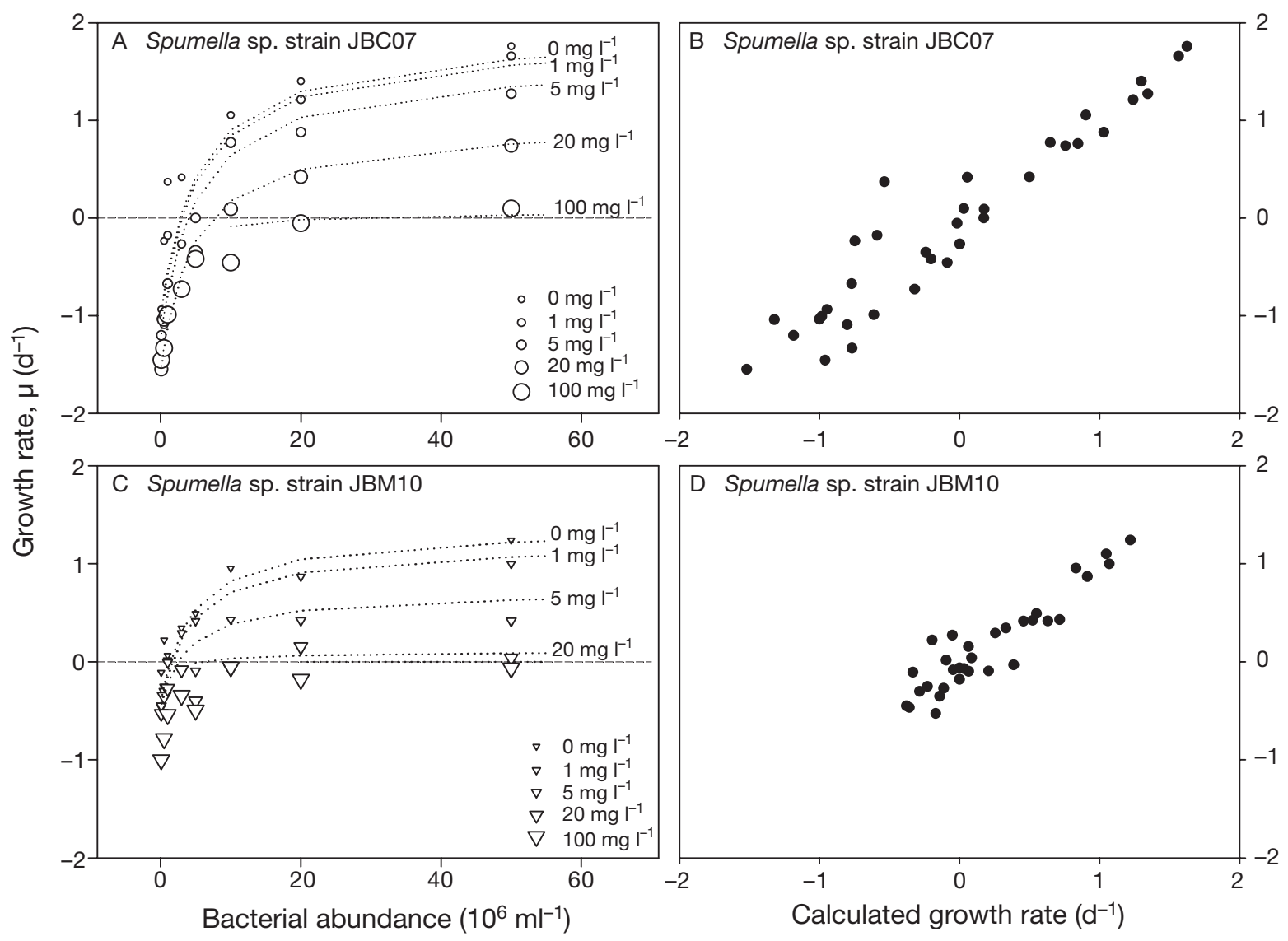

Fig. 4. Spumella sp. Effect of suspended clay and food concentration on the growth of bacterivorous flagellates. (A,C) Growth rates as functions of bacterial densities in the presence of 5 concentrations $\left(0,1,5,20\right.$ and $\left.100 \mathrm{mg} \mathrm{l}^{-1}\right)$ of suspended silicate particles $(0.8 \mu \mathrm{m})$. Dotted lines indicate the respective numerical response curves following Michaelis-Menten kinetics, allowing for an effect of suspended sediment concentration on the parameters $i, K_{m}$ and $\mu_{\max }$ (see 'Materials and methods' for explanation). (B,D) Fit of observed growth rates to model assumptions. Allowing for effects of both food concentration and suspended sediment concentration on growth rates, the models explained 90.4 and $85.4 \%$ of observed variation (see 'Results'). For the strain JBM10 the data points corresponding to $100 \mathrm{mg}$ suspended sediment $\mathrm{l}^{-1}$ were partly excluded as maximal growth rate is near 0 and, consequently, Michaelis-Menten kinetics become an inappropriate approximation 

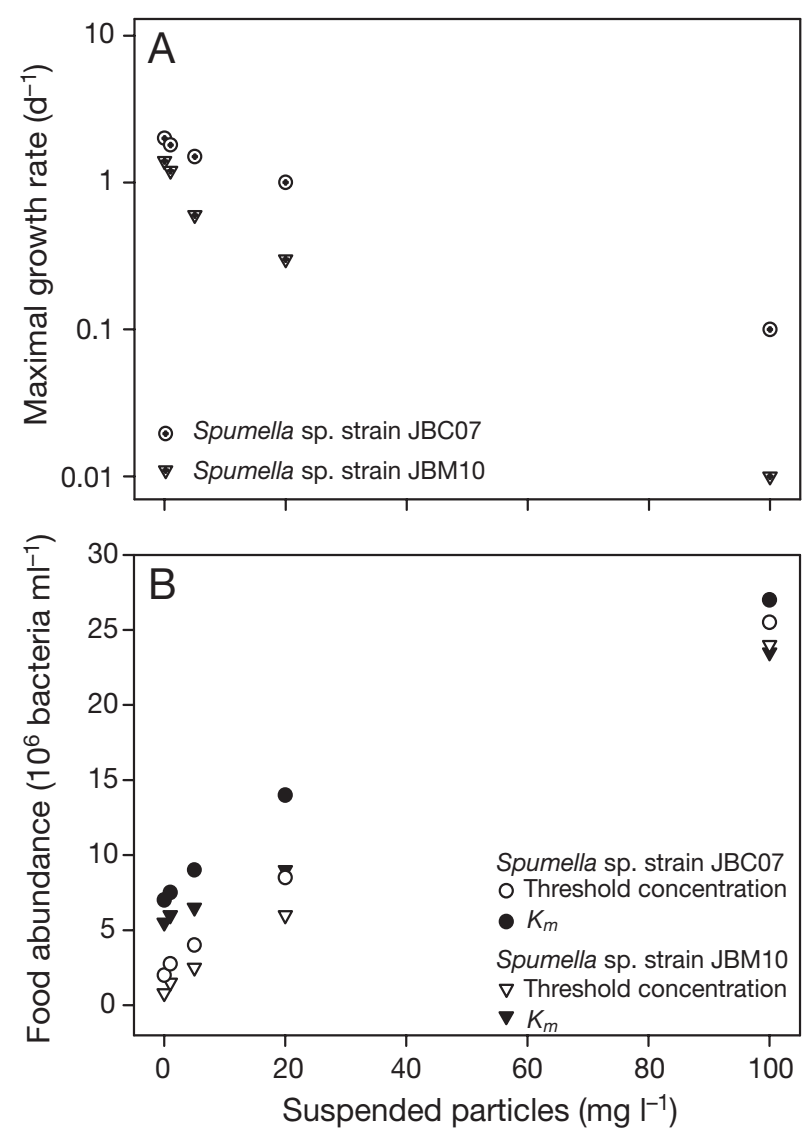

Fig. 5. Spumella sp. Growth kinetic parameters for the flagellate strains JBC07 and JBM10 as a function of suspended sediment concentration (silicate particles $0.8 \mu \mathrm{m}$ ). (A) Maximal growth rates and (B) threshold food concentrations and half-saturation constant values

In the absence of suspended sediments, the clearance rate for the flagellate strain JBC07 feeding on the bacterial strain MWH-MoNR1 was $5.46 \pm 0.14 \mathrm{nl}$ flagellate $^{-1} \mathrm{~h}^{-1}$. When pooling all data, the presence of suspended sediments affected flagellate clearance rates negatively ( $t$-test; $\mathrm{p}=0.002)$. We tested the effect of particle size both for a fixed particle concentration of $10 \mathrm{mg} \mathrm{l}^{-1}$ and for a fixed particle abundance of $1.49 \times$ $10^{7}$ particles $\mathrm{ml}^{-1}$. Regarding the fixed particle concentration of $10 \mathrm{mg} \mathrm{l}^{-1}$, a hump-shaped relationship with an optimum and decreasing values at lower and higher particle sizes (second-order polynomial regression model) was the best model to explain the change of clearance rates in dependence on suspended particle size $\left(r^{2}=0.64 ; p=0.003\right)$. The greatest effect of suspended sediments was found for small and large particles, and the least, for intermediate-sized particles of 3 $\mu \mathrm{m}$ (Fig. 6), i.e. clearance rates in the presence of intermediate-sized particles were higher than those for small and large particles.
Similarly, when the different-sized sediment particles were added at a fixed abundance of $1.49 \times 10^{7}$ particles $\mathrm{ml}^{-1}$, a hump-shaped relationship with an optimum and decreasing values at lower and higher particle sizes (second-order polynomial regression model) again was the best model to explain the change of clearance rates $\left(r^{2}=0.74 ; \mathrm{p} \leq 0.001\right)$. Optimum particle size, however, was smaller, i.e. the smallest effect of suspended sediment particles was found for the $1.5 \mu \mathrm{m}$ beads (Fig. 6).

\section{DISCUSSION}

\section{Growth kinetic parameters are correlated to suspended sediment concentration}

The growth rates of the flagellate strain JBC07 feeding on both bacteria fit with literature data (e.g. Jürgens 1994, Rothhaupt 1996a), and were generally sim-

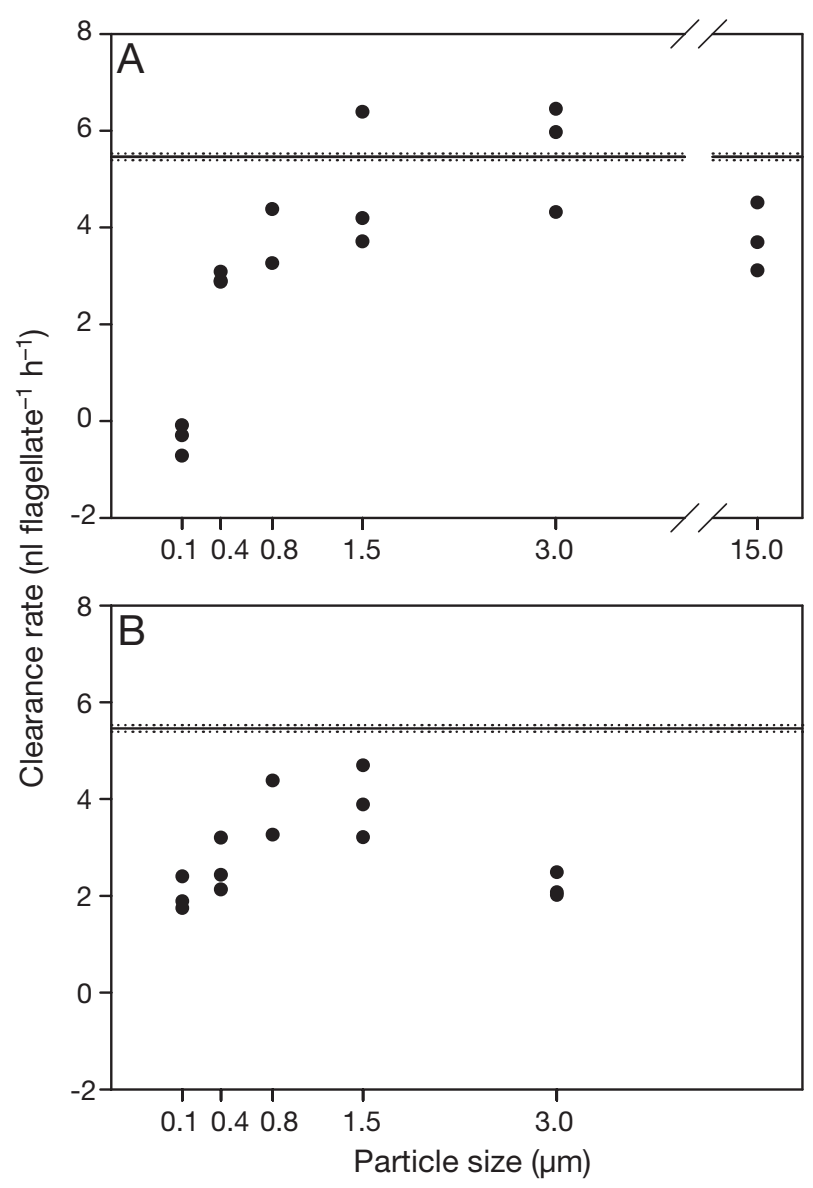

Fig. 6. Spumella sp. strain JBC07. Clearance rates in the presence of a constant (A) suspended particle load of $10 \mathrm{mg} \mathrm{l}^{-1}$ and (B) suspended particle abundance of $1.49 \times 10^{7}$ particles $\mathrm{ml}^{-1}$. Horizontal straight line represents the clearance rate of the control treatment without particles, and the dotted lines the respective standard deviation 
ilar to those of the flagellate strain JBM10 (Boenigk et al. 2006). However, in the second set of experiments, i.e. when the effect of suspended sediments was tested, threshold and $K_{m}$ values were somewhat lower. This may be due to the presence of traces of DOM in the latter experiments, i.e. either a direct stimulation of the flagellates or an indirect stimulation via bacterial growth. However, as bacterial abundances remained constant in our experiments (within the counting error) and the concentration of DOM was low, the responsible factors for the observed shifts in threshold and $K_{m}$ values remained vague. The fact that bacterial abundances did not significantly change in our experiments corresponded to our expectations, as growth rates of ultramircrobacteria are generally low, even under optimal conditions (Hahn 2003).

Direct interception implies that the predator propels water past itself and catches particles with which it collides (Fenchel 1987). Theoretical considerations suggest that suspended particles should affect the feeding efficiency of interception-feeding nanoflagellates, e.g. as individual particle handling is time consuming, a high density of non-food particles in the water is expected to strongly decrease the uptake of nutritive food and, therefore, negatively affect ingestion efficiency and subsequent growth of the flagellates (Boenigk \& Arndt 2002). Corresponding to these theoretical considerations, suspended sediments decreased the growth rates of the investigated flagellates in our experiments. The growth rates reflected literature data (Jürgens 1994, Rothhaupt 1996b), but the respective growth kinetic parameters $\left(K_{m}, i\right.$ and $\left.\mu\right)$ were correlated to the concentration of suspended sediments. Corresponding to the optimal foraging theory, the time periods for 1 instance of ingestion may be divided into the time spent 'searching' and the time spent 'handling'. For a low frequency of contacts (i.e. low particle abundance), the time spent 'handling' becomes negligible within the time budget of the flagellate and thus flagellate feeding and growth should be approximately related linearly to particle concentration. For a high frequency of contacts (i.e. high particle abundance), the time spent 'handling' becomes increasingly important and the increase in the ingestion and growth rates with increasing particle abundance should therefore increasingly deviate from a linear correlation, but better fit saturation kinetics (Boenigk \& Arndt 2000). This may explain the correlation between parameters of the numerical response and particle abundance in our experiment. Threshold value and $K_{m}$ (i.e. parameters mainly characterizing the course of the numerical response curve at low to intermediate food concentrations) were approximately linearly correlated with particle abundance, whereas $\mu_{\max }$ (i.e. a parameter mainly characterizing the course of the numerical response curve at high food concentrations) was exponentially correlated with particle concentration.

The negative effect of suspended particles on the growth of the Spumella-like flagellates can most probably be generalized, as the strength of the effect of suspended particles on the growth rates was similar for both investigated flagellate strains.

In contrast to our findings, we found in a former study (Boenigk \& Novarino 2004), a positive stimulation of the maximal growth rate of interception-feeding flagellates in the presence of clay particles. In that study, flagellates were directly transferred to the experiment from the stock culture. Further, experiments were run at satiating food concentrations using larger bacteria. Thus, residual growth and shifts in the feeding behavior at satiating food conditions may have overlaid the actual response to the experimental treatment. The results of that study must therefore be considered carefully. The discrepancy between these studies again highlights the importance of natural food concentrations and food particle size for estimating the effect of abiotic parameters on the growth of Spumella-like flagellates (cf. Boenigk et al. 2006).

\section{Strength of disturbance depends on particle size: mechanisms involved in the flagellate-particle interaction}

Interference with feeding, on the one hand, and attachment to particles to subsequently increase filtration efficiency, on the other hand, are the major components considered to affect the flagellate-particle interaction (Jack \& Gilbert 1993, Christensen-Daalsgard \& Fenchel 2003, Boenigk \& Novarino 2004). If this assumption is true, one would expect a strong effect of particle size in this interaction. In fact, we found that the particle size of suspended sediments is an important factor influencing the clearance rate of the Spumella-like flagellates. The clearance rates strongly decreased when small and large particles were present, but were only slightly affected by intermediate-sized particles of around $3 \mu \mathrm{m}$ in diameter. When small sediment particles in the range of ingestible bacteria were present, clearance rates were low, indicating that these particles interfere with the feeding process (see above). For intermediate-sized particles (around 1.5 to $3 \mu \mathrm{m}$ ), the negative effect of the suspended particles on the feeding process became negligible.

We suspect that the ingestion of intermediate-sized particles, and therefore the interference with the feeding process, becomes increasingly counterbalanced by increasing filtration efficiency due to attachment. 
Christensen-Dalsgaard \& Fenchel (2003) reported that the highest feeding flow produced by the flagellate was observed for cells attached to large particles that were still small enough for the cells to be able to pull them. This was judged to be a result of wall effects caused by the proximity of the surface of the particle. While Christensen-Daalsgard \& Fenchel (2003) reported the best particle size to attach was $25 \mu \mathrm{m}$ for Paraphysomonas vestita, optimal particle size for the Spumella strain used in this study was $<15 \mu \mathrm{m}$. The reduction of the ingestion efficiency is assumed to depend on the cell size of the flagellate, the distance of the center of force of the flagellum to the cell body and the length of the attachment thread. The small cell size of our flagellate strain JBC07 and also the very short or even absent attachment thread may consequently explain the difference of the optimal particle size between Spumella (present study) and $P$. vestita (Christensen-Daalsgard \& Fenchel 2003). When the number of particles was held constant (instead of the total particle weight), these size effects were overlaid by concentration-dependent effects. In this case optimal particle size was even around $1.5 \mu \mathrm{m}$. We assume that mechanical damage of the flagellate cells became of quantitative importance for larger particles.

\section{Significance of suspended sediments for chrysomonad flagellate field populations}

Colorless chrysophytes are an often dominating component of the microbial food web (Salbrechter \& Arndt 1994, Carrias et al. 1998, Finlay \& Esteban 1998, Arndt et al. 2000). Suspended clays and silts are also common in many lakes worldwide (Dokulil 1979, Gliwicz 1986, Threlkeld 1986, Hart 1988, Knowlton \& Jones 1995). Low annual mean concentrations of $<10 \mathrm{mg} \mathrm{l}^{-1}$ may increase to > $200 \mathrm{mg} \mathrm{l}^{-1}$ upon precipitation (Dokulil 1979, Knowlton \& Jones 1995). Despite the ubiquity of suspended sediments, however, their effect on this common and abundant flagellate group has hardly been studied (England et al. 1993, Jack \& Gilbert 1993, Boenigk \& Novarino 2004). Further, despite the vast literature on suspended sediment concentrations, the biologically relevant particle characteristics, i.e. particle size distribution and particle abundance, are rarely mentioned.

We could demonstrate that dominant protist taxa such as the chrysophytes are significantly affected by suspended sediments. Even slight shifts in the abiotic factors may make the difference between survival and death of the population at the food concentrations common in oligotrophic and mesotrophic lakes (i.e. 0.4 to 4

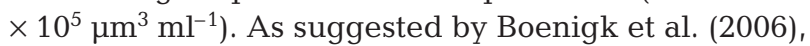
flagellates in oligotrophic and mesotrophic lakes are severely food limited and the bacterial biovolume should allow for low growth rates only. Thus, even slight shifts towards adverse abiotic conditions must be expected to lead to the mortality of at least some flagellate taxa. Accordingly, in our experiments, suspended clay concentrations of only 5 to $10 \mathrm{mg} \mathrm{l}^{-1}$ made a difference between net growth and net mortality at bacterial biovolumes realized in the field.

It should be noted that field populations of bacteria are more variable in size than those in our experiment, and thus a bacterial abundance of 2 to $4 \times 10^{6}$ bacteria $\mathrm{ml}^{-1}$ in the field corresponds roughly to a biovolume of 1 to $4 \times 10^{5} \mu^{3} \mathrm{ml}^{-1}$. In our experiments, we used 1 ultramicrobacterial strain, which is representative for freshwater bacterioplankton, but, of course, much less variable in size. In consequence, the abundance allowing for a net growth of the flagellates was around 5 to $10 \times 10^{6}$ bacteria $\mathrm{ml}^{-1}$ in our experiments. Still, the available bacterial biovolume (i.e. around 1 to $4 \times 10^{5}$ $\mu \mathrm{m}^{3} \mathrm{ml}^{-1}$ ) corresponded to that of bacterial field populations in oligotrophic and mesotrophic lakes.

In contrast to taxon-specific investigations, the effects of suspended sediments may not be striking on the community level (HNF or protists) and, thus, may lead to a false impression, i.e. that suspended particles do not matter. Accordingly, we found no negative effect of suspended clay on the community level in our study, but a strong effect on specific taxa. As we only investigated 1 model community, generalizations on the community level are, so far, difficult. The significance of particular particle characteristics such as surface load, form and ion exchange capacity is not well understood either (but see Boenigk et al. 2005a). The efffect of suspended particles may differ markedly depending on the types of particles introduced and on the taxonomic composition of the flagellate community. Further studies on different flagellate communities and using different types of suspended sediments are therefore desirable. We suspect, however, that particle abundance and particle size distribution are mainly responsible for the specific particle-protist interaction and that purely pelagic flagellates may generally be negatively affected, whereas flagellate taxa that are commonly associated with sediments (i.e. benthic flagellates, soil flagellates and flagellates attached to substrate flocs [e.g. bodonids as observed in our experiment; data not shown]) may even be stimulated. Still, these interactions may be further modified by bacterial aggregation or biofilm formation, i.e. factors that were excluded from our experiment by choosing the model food bacterium.

Shifts in the concentration of suspended sediments in the field are also usually linked to shifts in turbulence and DOM supply. The latter factors have both been shown to affect flagellate growth directly and 
indirectly via stimulation of bacterial growth (e.g. Peters et al. 2002, Dolan et al. 2003, Havskum et al. 2003). It may, therefore, be difficult to separate effects of suspended sediments from those of DOM supply and turbulence in the field, specifically as different taxa may respond differently to these factors. However, our results provide evidence of the significance of suspended sediments for the growth of bacterivorous protists, specifically of colorless chrysomonads.

In conclusion, suspended sediments are a crucial, but so far underestimated, factor for bacterivorous protists. Our results imply a strong taxon-specific response to suspended sediment load already at low suspended sediment concentrations. The ecological response of different bacterivorous protist taxa to suspended sediment load is consequently a key issue towards a better understanding of microbial dynamics, specifically in small or turbulent water bodies.

Acknowledgements. The authors thank A. Wiedlroither and L. Eisl for their skillful technical assistance. Furthermore, we thank the Austrian Science Fund for the financial support provided (FWF project P15940).

\section{LITERATURE CITED}

Arndt H, Dietrich D, Auer B, Cleven EJ, Gräfenhan T, Weitere M, Mylnikov AP (2000) Functional diversity of heterotrophic flagellates in aquatic ecosystems. In: Leadbeater BSC, Green JC (eds) The flagellates. Taylor \& Francis, London, p 240-268

Arruda JA, Marzolf GR, Faulk RT (1983) The role of suspended sediments in the nutrition of zooplankton in turbid reservoirs. Ecology 64:1225-1235

Boenigk J, Arndt H (2000) Particle handling during interception feeding by four species of heterotrophic flagellates. J Eukaryot Microbiol 47:350-358

Boenigk J, Arndt H (2002) Bacterivory by heterotrophic flagellates: community structure and feeding strategies. Antonie Leeuwenhoek 81:465-480

Boenigk J, Novarino G (2004) Effect of suspended clay on the feeding and growth of bacterivorous flagellates and ciliates. Aquat Microb Ecol 34:181-192

Boenigk J, Wiedlroither A, Pfandl K (2005a) Heavy metal toxicity and bioavailability of dissolved nutrients to a bacterivorous flagellate are linked to suspended particle physical properties. Aquat Toxicol 71:249-259

Boenigk J, Pfandl K, Stadler P, Chatzinotas A (2005b) High diversity of the 'Spumella-like' flagellates: an investigation based on the SSU rRNA gene sequences of isolates from habitats located in six different geographic regions. Environ Microbiol 7:685-697

Boenigk J, Stadler P, Wiedlroither A, Hahn MW (2005c) Strain-specific differences in the grazing sensitivities of closely related ultramicrobacteria affiliated with the Polynucleobacter cluster. Appl Environ Microbiol 70: 5787-5793

Boenigk J, Pfandl K, Hansen PJ (2006) Exploring strategies for nanoflagellates living in a 'wet desert'. Aquat Microb Ecol 44:71-83

Brondson RK, Naden PS (2000) Suspended sediment in the river Tweed and Teviot. Sci Total Environ 251/252:95-113 Carrias JF, Amblard C, Quiblier-Lloberas C, Bourdier G (1998) Seasonal dynamics of free and attached heterotrophic nanoflagellates in an oligomesotrophic lake. Freshw Biol 39:91-101

Christensen-Dalsgaard KK, Fenchel T (2003) Increased filtration efficiency of attached compared to free-swimming flagellates. Aquat Microb Ecol 33:77-86

Dokulil M (1979) Optical properties, colour and turbidity. In: Löffler H (ed) Neusiedlersee: the limnology of a shallow lake in central Europe. Dr W Junk Publishers, The Hague, p 151-167

Dolan JR, Sall N, Metcalfe A, Gasser B (2003) Effects of turbulence on the feeding and growth of a marine oligotrich ciliate. Aquat Microb Ecol 31:183-192

Eisma D (1993) Suspended matter in the aquatic environment. Springer-Verlag, Berlin

England LS, Lee H, Trevors JT (1993) Bacterial survival in soil: effect of clays and Protozoa. Soil Biol Biochem 25: $525-531$

Fenchel T (1987) Ecology of protozoa. In: Brock TD (ed) The biology of free-living phagotrophic protists. Science Tech Publishers, Madison, WI, p 32-52

Finlay BJ, Esteban GF (1998) Freshwater protozoa: biodiversity and ecological function. Biodivers Conserv 7 : $1163-1186$

Gliwicz MZ (1986) Suspended clay concentration controlled by filter-feeding zooplankton in a tropical reservoir. Nature 323:330-332

Hahn MW (2003) Isolation of strains belonging to the cosmopolitan Polynucleobacter necessaries cluster from freshwater habitats located in three climatic zones. Appl Environ Microbiol 69:5248-5254

Hahn MW, Höfle MG (1998) Grazing pressure by a bacterivorous flagellate reverses the relative abundance of Comamonas acidovorans PX54 and Vibrio strain CB5 in chemostat coculture. Appl Environ Microbiol 64:1910-1918

Hahn MW, Lünsdorf $H$, Wu Q, Schauer M, Höfle MG, Boenigk J, Stadler P (2003) Isolation of novel ultramicrobacteria classified as Actinobacteria from five freshwater habitats in Europe and Asia. Appl Environ Microbiol 69:1442-1451

Hart RC (1988) Zooplankton feeding rates in relation to suspended sediment content; potential influences on community structure in a turbid reservoir. Freshw Biol 19:123-139

Havskum H, Thingstad TF, Scharek R, Peters F and 8 others (2003) Silicate and labile DOC interfere in structuring the microbial food web via algal-bacterial competition for mineral nutrients: results of a mesocosm experiment. Limnol Oceanogr 48:129-140

Jack JD, Gilbert JJ (1993) The effect of suspended clay on ciliate population growth rates. Freshw Biol 29:385-394

Jürgens K (1994) Die Bedeutung heterotropher Nanoflagellaten als Bakterienkonsumenten sowie deren Regulation durch Prädation und Ressourcen. Christian-AlbrechtsUniversität Kiel, Plön

Kiørboe T, Grossart HP, Ploug H, Tang K, Auer B (2004) Particle-associated flagellates: swimming patterns, colonization rates, and grazing on attached bacteria. Aquat Microb Ecol 35:141-152

Knowlton MF, Jones JR (1995) Temporal and spatial dynamics of suspended sediment, nutrients, and algal biomass in Mark Twain Lake, Missouri. Arch Hydrobiol 135:145-178

Lenzi MA, Marchi L (2000) Suspended sediment load during floods in a small stream in the Dolomites (northeastern Italy). Catena 39:267-282 
Lind OT, Chrzanowski TH, Dávalos-Lind L (1997) Clay turbidity and the relative production of bacterioplankton and phytoplankton. Hydrobiologia 353:1-18

Orton PM, Kineke GC (2001) Comparing calculated and observed vertical suspended-sediment distributions from a Hudson River Estuary turbidity maximum. Estuar Coast Shelf Sci 52:401-410

Peters F, Marrasé C, Havskum H, Rassoulzadegan F, Dolan J, Alcaraz M, Gasol JM (2002) Turbulence and the microbial food web: effects on bacterial losses to predation and on community structure. J Plankton Res 24:321-331

Ritchie JC, Schiebe FR, Cooper CM (1986) Surface water quality measurements of Lake Chicot, Arkansas using data from Landsat satellites. J Freshw Ecol 3:391-397

Editorial responsibility: Klaus Jürgens,

Rostock, Germany
Rothhaupt KO (1996a) Laboratory experiments with a mixotrophic chrysophyte and obligately phagotrophic and phototrophic competitors. Ecology 77:716-724

Rothhaupt KO (1996b) Utilization of substitutable carbon and phosphorus sources by the mixotrophic chrysophyte Ochromonas sp. Ecology 77:706-715

Salbrechter M, Arndt H (1994) The annual cycle of protozooplankton in the alpine-mesotrophic Lake Mondsee (Austria). Mar Microb Food Webs 8:217-234

Serruya S (1974) The mixing patterns of the Jordan River in Lake Kinneret. Limnol Oceanogr 34:673-687

Threlkeld ST (1986) Life table responses and population dynamics of four cladoceran zooplankton during a reservoir flood. J Plankton Res 8:639-647

Submitted: April 6, 2006; Accepted: August 31, 2006

Proofs received from author(s): October 13, 2006 